RESEARCH REPORT

\title{
Increased resting heart rate with pollutants in a population based study
}

\author{
Jean-Bernard Ruidavets, Sylvie Cassadou, Maxime Cournot, Vincent Bataille, Mariam Meybeck, \\ Jean Ferrières
}

J Epidemiol Community Health 2005;59:685-693. doi: 10.1136/jech.2004.026252

\begin{abstract}
See end of article for authors' affiliations

Correspondence to:

Dr J-B Ruidavets, INSERM

U558, Faculté de

Médecine, 37 allées Jules

Guesde, 31073 Toulouse

cedex, France;

jean-bernard.ruidavets@

cict.fr

Accepted for publication

7 March 2005
\end{abstract}

\begin{abstract}
Background: Air pollution is associated with cardiovascular mortality. Changes in the autonomic nervous system may contribute to cardiac arrhythmias and cardiovascular mortality. This study investigated the relations between air pollutant concentrations of sulphur dioxide $\left(\mathrm{SO}_{2}\right)$, ozone $\left(\mathrm{O}_{3}\right)$, nitric dioxide $\left(\mathrm{NO}_{2}\right)$, and resting heart rate (RHR) in a population based study.

Methods: A sample of 863 middle aged men and women, living in Toulouse (MONICA centre) area, was randomly recruited. A cross sectional survey on cardiovascular risk factors was carried. RHR was measured twice in a sitting position after a five minute rest. Multivariate analyses with quintiles of RHR were performed using polytomous logistic regression. Models were adjusted for temperature, season, relative humidity, sex, physical activity, blood pressure, $\mathrm{C}$ reactive protein, and cardiovascular drugs. Results: For $\mathrm{NO}_{2}$, the OR (odds ratio) $\left(95 \% \mathrm{Cl}\right.$ ) associated with an increase of $5 \mu \mathrm{g} / \mathrm{m}^{3}$ in the current day of medical examination was 1.14 (1.03 to 1.25) in quintile Q5 of RHR compared with Q1, p for trend $=0.003$. For $\mathrm{SO}_{2}, \mathrm{OR}$ was 1.16 (0.94 to 1.44) in $\mathrm{Q} 5$ compared with $\mathrm{Q} 1$, $p$ for trend $=0.05$, and for $\mathrm{O}_{3}, \mathrm{OR}$ was 0.96 (0.91 to 1.01) in Q5 compared with Q1, $\mathrm{p}$ for trend $=0.11$. No significant association was seen when the daily mean concentration of $\mathrm{NO}_{2}, \mathrm{SO}_{2}$, and $\mathrm{O}_{3}$ was considered during the previous day as well as when day lag 2 or 3 was considered. The cumulative concentration (three consecutive days) of $\mathrm{O}_{3}$ is negatively associated with RHR ( $p$ for trend $=0.02$ ).

Conclusion: Changes in pulse rate could reflect cardiac rhythm changes and may be part of the pathophysiological link between pollution and cardiovascular mortality.
\end{abstract}

E pidemiological studies have shown that air pollution is associated with increased cardiovascular morbidity and , nitrogen dioxide, carbon monoxide, and particulate matter) are potential candidate for a deleterious effect on the vascular system via various pathophysiological mechanisms: oxidative stress and inflammation or by direct effect of pollutants on endothelial dysfunction and arterial tone disturbance or via autonomic nervous system alteration. ${ }^{67}$ In habitual conditions of exposure, the influence and the deleterious effects of gaseous pollutants, nitric dioxide $\left(\mathrm{NO}_{2}\right)$, sulphur dioxide $\left(\mathrm{SO}_{2}\right)$, and ozone $\left(\mathrm{O}_{3}\right)$, on the systemic system have not been extensively studied. In particular the relation between heart rate and gaseous pollutants has been insufficiently investigated in epidemiological methodology studies. Ambient concentrations of PM2.5 and ozone can reduce the high frequency component of heart rate variability in elderly and hypertensive subjects apparently more vulnerable. ${ }^{8}$ Increased air pollutants $\left(\mathrm{NO}_{2}\right)$ are associated with increased defibrillator interventions. ${ }^{9}$ Resting heart rate (RHR) is known to be a predictor of mortality (all causes of mortality and cardiovascular mortality), independent of classic cardiovascular risk factors. ${ }^{10-13}$ The air pollution episode in Central Europe in January 1985 concomitant with the first MONICA (monitoring of trends and determinants in cardiovascular disease) population survey carried out in Augsburg was used to test the associations between air pollution and RHR. ${ }^{14}$ Acceleration in heart rates suggested that changed autonomic control of the heart was associated with air pollution. Changes in pulse rate could reflect cardiac rhythm changes and may be part of the pathophysiological link between pollution and cardiopulmonary mortality. ${ }^{15} \mathrm{We}$ investigated the relation between air pollutant concentrations and RHR in a cross sectional population based study carried out in the metropolitan area of Toulouse.

\section{METHODS}

\section{Population sampling}

A cross sectional survey on cardiovascular risk factors was carried out from 1995 to 1997 by the Toulouse MONICA centre. ${ }^{16}{ }^{17}$ A sample of 1182 middle aged men and women (35 to 64 years) living in Toulouse (south western France) area was randomly recruited. Polling lists (nominal lists for French inhabitants aged over 18 years) available in each town hall of the survey area were used for sampling to carry out a random selection of the general population. A stratified random sampling was used. Strata were town size, age (10 year age groups), and sex. Participants were volunteers and received no financial compensation. The response rate reached $60 \%$ of the contacted people. The study protocol was approved by an institutional review committee in agreement with the French Law on Human Biomedical Research. An informed consent to participate in the study was obtained from each subject. Among subjects selected at random, only subjects living in the Toulouse area covered by urban monitoring stations were included for statistical analysis. There were no other criteria for inclusion. Among 1182 subjects recruited initially, only 863 persons met these required criteria.

\section{Collected questionnaires}

Extensive questionnaires were completed by the participants with the help of trained and certified medical staff. Data on

Abbreviations: $\mathrm{RHR}$, resting heart rate; $\mathrm{SO}_{2}$, sulphur dioxide; $\mathrm{O}_{3}$, ozone; $\mathrm{NO}_{2}$, nitric dioxide 
age, socioeconomic status, occupational activity, medical history, drug intake, cardiovascular risk factors including smoking habits (past and present behaviour and the number of cigarettes, pipes, or cigars smoked), and lifestyle were collected. Education level was assessed by the report of the number of completed years of schooling (from the beginning of the primary school until graduation or school drop out). Four levels of leisure time physical activity were defined: no regular physical activity, light physical activity (that is, less than once a week), moderate physical activity (that is, 20 minutes at least, once or twice a week), and high physical activity (that is, 20 minutes at least, three times a week or more).

\section{Clinical and biological measurements}

Subjects were screened on the morning, from Monday to Friday (no examination was done on Saturdays and Sundays), in the same health centre administered by the social security system and located approximately in the centre of the area studied. The medical examination took around 150 minutes, starting with information given to the subjects about the aim of the study, they then read, completed, and signed a formal consent form. The screening was followed by a blood sample collection and then a small snack was offered. The examination was followed by the completion of a questionnaire (lasting for about 20 minutes) and then clinical measurements were taken: blood pressure and heart rate. The clinical examination took place 40 minutes after the arrival of the subjects in the centre.

Anthropometrical measurements including height, body weight, waist and hip circumferences were taken in agreement with standardised procedures between $830 \mathrm{am}$ and $1030 \mathrm{am}^{16}{ }^{17}$ Body mass index (BMI) and waist to hip ratio (WHR) were computed as follows: weight $(\mathrm{kg}) / \mathrm{height}\left(\mathrm{m}^{2}\right)$ and waist/hip respectively. Blood pressure and heart rate were measured twice in a sitting position after a five minute rest. Blood pressure was measured on the right arm with a standard mercury sphygmomanometer. Measurements were rounded to the nearest $2 \mathrm{~mm} \mathrm{Hg}$. Pulse palpation was measured for 60 seconds. The average of the two measurements was used for the statistical analysis. Blood samples were taken after at least 10 hours of overnight fasting. C reactive protein (CRP) concentrations were measured by an immunonephelemetric method (Dade Behring Marburg $\mathrm{GmbH}$, Marburg, Germany). Room temperature was recorded during blood pressure and RHR measurements.

\section{Air pollution and meteorological variables}

Gas pollutant concentrations were measured hourly as part of the automated Midi-Pyrenees air quality network (ORAMIP). $\mathrm{SO}_{2}$ concentrations were measured by ultraviolet fluorescence, $\mathrm{NO}_{2}$ concentrations were measured by chemiluminescences, and $\mathrm{O}_{3}$ concentrations were measured by ultraviolet photometry.

Data provided by urban monitoring stations were taken into account to test the relations between air pollutants and RHR, because the goal of the study was to estimate the average daily exposure-response relation. ${ }^{18}$ France has a nationally standardised classification system for air quality monitoring stations, and the rules regulating station operations are very strict. ${ }^{19}$ For each pollutant $\left(\mathrm{NO}_{2}\right.$ and $\left.\mathrm{SO}_{2}\right)$, the 24 hour mean concentration was calculated from midnight to midnight and took into account the results from all the urban monitoring stations. For $\mathrm{O}_{3}$, the moving average of the eight consecutive hours with the highest values of the day was taken into account in the statistical analysis.

Mean daily temperature $\left({ }^{\circ} \mathrm{C}\right)$ for the minimum and the maximum, and relative humidity (\%) were available from the weather station located in the metropolitan area of Toulouse. These weather variables were selected to control potential weather effects using a synoptic climatological approach. ${ }^{20}$ Data on influenza episodes, expressed as the number of

Table 1 Characteristics of the study population $(n=863)$

\begin{tabular}{|c|c|c|c|c|}
\hline & Mean & Median & SD & Range \\
\hline Age (y) & 49.6 & 49.0 & 8.5 & $35-65$ \\
\hline BMI $\left(\mathrm{kg} / \mathrm{m}^{2}\right)$ & 25.1 & 24.8 & 3.9 & $16.3-44.5$ \\
\hline Waist to hip ratio & 0.88 & 0.89 & 0.09 & $0.65-1.18$ \\
\hline $\mathrm{SBP}(\mathrm{mm} \mathrm{Hg})$ & 130.2 & 128 & 17.3 & $98-210$ \\
\hline $\mathrm{DBP}(\mathrm{mm} \mathrm{Hg})$ & 79.4 & 79 & 10.2 & $48-115$ \\
\hline Resting heart rate (bpm) & 67.5 & 67.5 & 9.1 & $43.5-106.5$ \\
\hline Alcohol consumption (g/d) & 18.2 & 7.9 & 24.2 & $0-140$ \\
\hline $\mathrm{C}$ reactive protein $(\mathrm{mg} / \mathrm{l})$ & 1.6 & 0.7 & 3.5 & $0.2-71$ \\
\hline Room temperature during examination ${ }^{\circ} \mathrm{C}$ & 23.2 & 23.0 & 1.7 & $18-33$ \\
\hline Sex (\% male) & 50.3 & & & \\
\hline \multicolumn{5}{|l|}{ Level of education $\%$} \\
\hline university & 30.5 & & & \\
\hline secondary school & 52.9 & & & \\
\hline primary school & 16.6 & & & \\
\hline \multicolumn{5}{|l|}{ Socio-professional status \% } \\
\hline white collar workers & 23.6 & & & \\
\hline intermediate workers & 46.8 & & & \\
\hline blue collar workers & 29.6 & & & \\
\hline \multicolumn{5}{|l|}{ Occupational status (\%) } \\
\hline employed & 67.2 & & & \\
\hline unemployed, invalid & 15.8 & & & \\
\hline retired & 17.0 & & & \\
\hline Current smoking $\%$ & 21.7 & & & \\
\hline Physical activity \% & 46.6 & & & \\
\hline History of ischaemic heart disease & 2.2 & & & \\
\hline Conduction defect or arrhythmia & 0.9 & & & \\
\hline Chronic obstructive pulmonary disease & 1.3 & & & \\
\hline \multicolumn{5}{|l|}{ Treatment \% for } \\
\hline dyslipidaemia & 13.1 & & & \\
\hline hypertension & 13.0 & & & \\
\hline diabetes & 2.9 & & & \\
\hline
\end{tabular}


Table 2 Distribution of air pollution and weather variables with Spearman rank correlations

\begin{tabular}{|c|c|c|c|c|c|c|c|c|}
\hline & \multirow[b]{2}{*}{ Mean } & \multirow[b]{2}{*}{ SD } & \multirow[b]{2}{*}{ Range } & \multicolumn{5}{|l|}{ Centile } \\
\hline & & & & 10th & 25th & 50 th & 75th & 90th \\
\hline $\mathrm{NO}_{2} \mu \mathrm{g} / \mathrm{m}^{3}$ & 30.3 & 12.1 & 7.0 to 90.7 & 16.6 & 22.0 & 28.4 & 37.3 & 45.6 \\
\hline $\mathrm{SO}_{2} \mu \mathrm{g} / \mathrm{m}^{3}$ & 13.3 & 7.5 & 1.3 to 47.7 & 5.1 & 8.1 & 12.0 & 16.5 & 27.9 \\
\hline $\mathrm{O}_{3} \mu \mathrm{g} / \mathrm{m}^{3}$ & 76.5 & 29.6 & 4.2 to 160.6 & 39.8 & 56.6 & 74.3 & 93.8 & 118.3 \\
\hline Temperature (maximum) ${ }^{\circ} \mathrm{C}$ & 18.3 & 7.4 & -0.4 to 34.8 & 9.5 & 12.9 & 17.2 & 24.1 & 29.1 \\
\hline Temperature (minimum) ${ }^{\circ} \mathrm{C}$ & 9.0 & 6.1 & -6.3 to 21.6 & 0.8 & 4.6 & 8.9 & 13.8 & 17.7 \\
\hline \multirow[t]{2}{*}{ Relative humidity (\%) } & 51.6 & 16.7 & 14 to 96 & 30 & 39 & 50 & 64 & $\begin{array}{l}75 \\
\text { Influenzae }\end{array}$ \\
\hline & & & $\mathrm{SO}_{2}$ & $\mathrm{O}_{3}$ & $\mathrm{~T}^{\circ} \mathrm{Max}$ & $\mathrm{T}^{\circ} \mathrm{Min}$ & Humidity & episodes \\
\hline $\mathrm{NO}_{2} \mu \mathrm{g} / \mathrm{m}^{3}$ & & & 0.74 & -0.32 & -0.29 & -0.53 & 0.05 & 0.31 \\
\hline $\mathrm{SO}_{2} \mu \mathrm{g} / \mathrm{m}^{3}$ & & & & -0.28 & -0.18 & -0.36 & -0.03 & 0.26 \\
\hline $\mathrm{O}_{3} \mu \mathrm{g} / \mathrm{m}^{3}$ & & & & & 0.71 & 0.54 & -0.72 & -0.37 \\
\hline Temperature maximum & & & & & & 0.84 & -0.63 & -0.53 \\
\hline Temperature minimum & & & & & & & -0.27 & -0.55 \\
\hline Relative humidity & & & & & & & & 0.32 \\
\hline
\end{tabular}

occurrences per week, were obtained from a general practitioner sentinel network of the metropolitan area of Toulouse.

A standardised procedure was used to fill in days with missing data. ${ }^{21} \mathrm{~A}$ missing value on day $i$ in year $k$ in monitoring station $j$ was replaced by a weighted average value of the values from the rest of the monitoring stations, that is

$$
\hat{\mathrm{Y}}_{\mathrm{ijk}}=\overline{\mathrm{Y}}_{\mathrm{j} . \mathrm{k}} \times\left(\overline{\mathrm{Y}}_{\mathrm{jk}} / \overline{\mathrm{Y}}_{\mathrm{.k}}\right)
$$

Globally, the proportion of missing values in relation to the total values of pollutants measured was around $2 \%$.

\section{Statistical analysis}

All the statistical analyses were performed using data of mean air pollutant concentrations recorded on the same day of the medical examination and on day lag 1, 2, 3 for $\mathrm{SO}_{2}, \mathrm{O}_{3}$, and $\mathrm{NO}_{2}$. The cumulative effect of each pollutant was evaluated on the basis of the three day mean concentration (day lag $1+$ day lag $2+$ day lag 3 ).

Moreover, for the concurrent day (the same day for the medical examination and the pollutant measurements) the average value of the concentration of each pollutant was calculated for the period before the medical examination $(0-8$ $\mathrm{am})$, for the period including the period before and the period of the examination (0-12 am), and lastly for the period after the examination ( $12 \mathrm{am}-12 \mathrm{pm}$ ).

Multivariate analyses with quintiles of RHR were performed using polytomous logistic regression, to test the association between each daily mean air pollutant concentration and RHR. The four cut offs of the RHR quintiles were $60.0,64.5,69.0$, and 75.0 beat/min respectively.

Adjustment for individual and environmental variables was done first. The variables were selected to be entered into the model when bivariate statistical associations with RHR reached $\mathrm{p}<0.10$; sex, physical activity, alcohol consumption, blood pressure, BMI, WHR, CRP, season, outdoor temperature, relative humidity, or when the associations had been reported in scientific literature-that is, age, sex, BMI, tobacco consumption, season, or drugs known to regulate heart frequency ( $\beta$ blockers for example) or when weather conditions, such as relative humidity and temperature favoured solubility and bioavailability of some pollutants, reinforcing their toxicity. ${ }^{22}$ The variables entered in the original model were age, sex, physical activity, tobacco and alcohol consumption, BMI, systolic blood pressure, cardiovascular drug use, CRP, outdoor temperature, relative humidity, and season (months).
A backward selection method of the variables for all the models was used. Firstly, all selected variables were entered in a full model and then a step by step elimination was performed. A likelihood ratio test was made between nested models to remove non-significant contributory variables. The final model for $\mathrm{NO}_{2}$ and $\mathrm{SO}_{2}$ comprised the following covariates: sex, physical activity, systolic blood pressure, cardiovascular drug use, CRP, relative humidity, and season (months). For $\mathrm{O}_{3}$, an additional adjustment for outdoor temperature was done. The substitution of outdoor temperature by indoor temperature measured during blood pressure and heart rate measurements had no impact. The use of WHR in place of BMI in the statistical models did not modify the relations significantly.

We considered $\mathrm{p}<0.05$ as significant. Statistical analyses were conducted using SAS (SAS Institute, version 6, Cary, NC) and Stata (Stata, release 6.0, College Station, TX).

\section{RESULTS}

Table 1 shows the major characteristics of the studied population. Globally the participants were apparently healthy and about $4 \%$ of the population sample reported disorders susceptible to influence the relation between exposure and RHR. Among responders, 19 subjects declared a personal history of ischaemic heart disease, eight reported conduction defect or arrhythmia abnormalities, and 11 reported chronic obstructive pulmonary disease.

In table 2 the distributions of air pollution and weather variables with Spearman correlations are reported. The concentrations of pollutants and weather variables given correspond to the inclusion period of the subjects in the survey. During the study period, the values of air pollutants measured never exceeded the alert point value.

In figure 1, air concentrations of $\mathrm{NO}_{2}, \mathrm{SO}_{2}$, and $\mathrm{O}_{3}$ are presented according to the season. As expected, air concentrations of $\mathrm{NO}_{2}$ were the highest in winter and in spring, air concentrations of $\mathrm{SO}_{2}$ were the highest in winter and autumn, and air concentrations of $\mathrm{O}_{3}$ were the highest in summer. Seasons were adjusted variables in the multivariate model.

The box plots of the air concentrations of $\mathrm{NO}_{2}, \mathrm{SO}_{2}$, and $\mathrm{O}_{3}$ (mean values before medical examination from $0 \mathrm{am}$ to $8 \mathrm{am}$ ) according to the quintiles of the RHRs are given in figure 2. The trend according to RHR quintiles for $\mathrm{NO}_{2}$ increased and the trend for $\mathrm{O}_{3}$ decreased. The relation between air concentration of $\mathrm{SO}_{2}$ and RHR was stable.

Table 3 gives the ORs (odds ratio) of daily and cumulative levels of air pollutants according to the quintiles of RHR. For the day of the medical examination, the relations between 

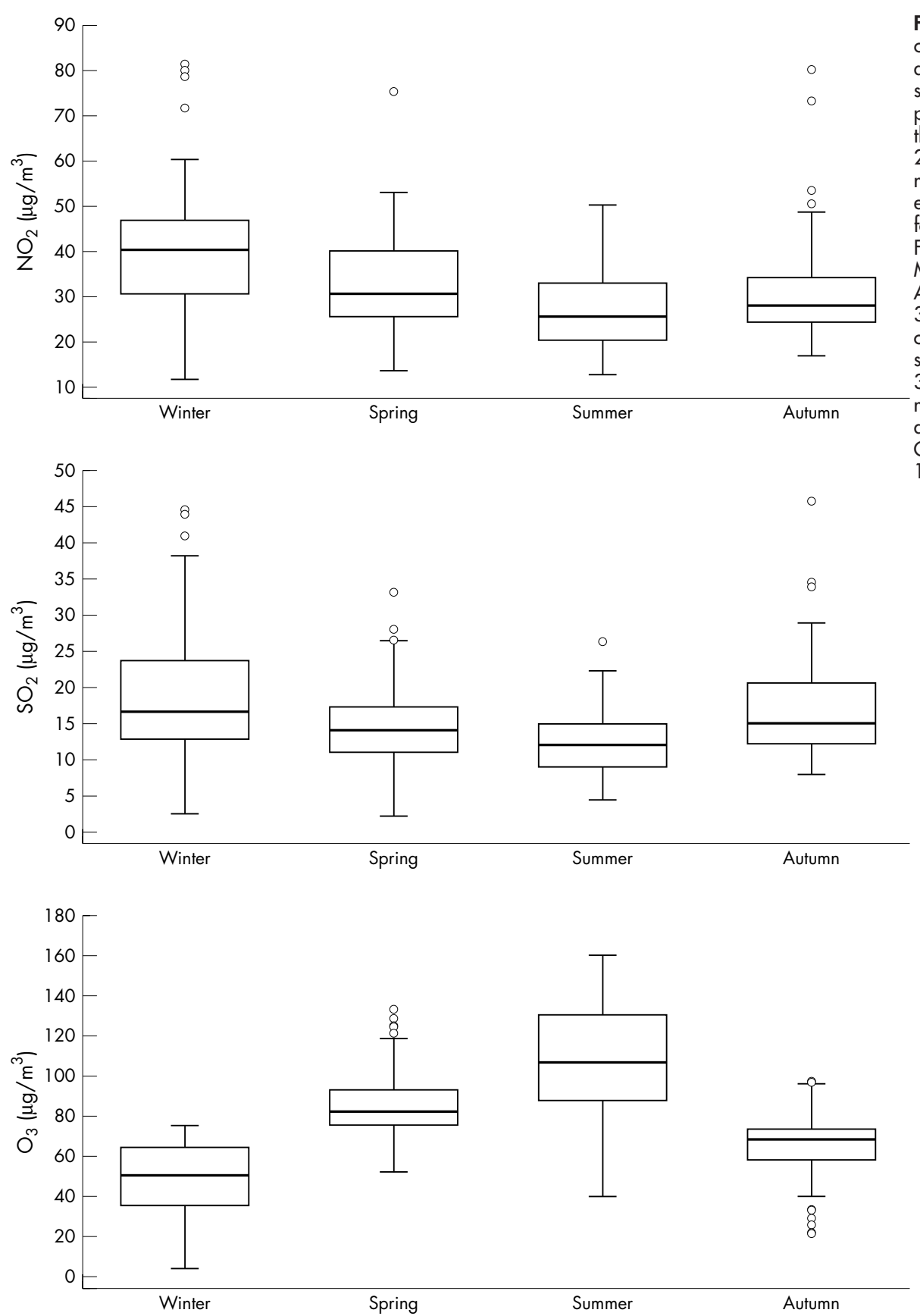

Figure 1 Box plots of air pollution concentrations $\left(\mathrm{NO}_{2}, \mathrm{SO}_{2}, \mathrm{O}_{3}\right)$ according to the season during the study period. The values of air pollutants correspond to the average of the crude measurement values over 24 hours. The values shown are those measured on the day of the medical examination. Seasons were defined as follows: winter from 1 December to 28 February, spring from 1 March to 31

May, summer from 1 June to 31

August, autumn from 1 September to 30 November. For $\mathrm{NO}_{2}$ the distribution of mean values according to the seasons were $39.1,31.8,26.8$, and $30.4 \mu \mathrm{g} / \mathrm{m}^{3}$ respectively, for $\mathrm{SO}_{2}$ the mean values were $18.6,14.2,12.3$, and $16.8 \mu \mathrm{g} / \mathrm{m}^{3}$ respectively, and for $\mathrm{O}_{3}$ the mean values were $49.0,86.2$, 108.8 , and $66.8 \mu \mathrm{g} / \mathrm{m}^{3}$ respectively. gaseous pollutants and RHR were given for the global concurrent day of exposure and for the periods before and after the examination. After a multivariate adjustment, the OR for $\mathrm{NO}_{2}$ in quintile 5 of RHR was significantly higher than in the reference quintile (number 1) considering the whole day of exposure or the periods of exposure from 0 am to 8 am or from $0 \mathrm{am}$ to $12 \mathrm{am}$. The trends of these associations were statistically significant. No significant association was seen when the period of exposure ( 12 am to $12 \mathrm{pm}$ ) after examination (Q5 compared with Q1) was considered. Similarly, non-significant association of $\mathrm{NO}_{2}$ concentration was seen during the previous days (day lag 1, 2, or 3) and no cumulative concentration of $\mathrm{NO}_{2}$ seen over three days. Only the tests for trend were significant. For $\mathrm{SO}_{2}$ pollutant, the Q5 compared with Q1 quintile comparison was statistically significant for the whole concurrent day of exposure and when the period of exposure ( 12 am to $12 \mathrm{pm}$ ) after the examination was considered. The trends of the associations between $\mathrm{SO}_{2}$ and RHR were significant. By contrast, no significant association was reported for $\mathrm{O}_{3}$ whatever the day or the cumulative effect considered when the fifth quintile was compared with the reference quintile. The trend was significant $(\mathrm{p}=0.02)$ for $\mathrm{O}_{3}$ when the average of the three consecutive days (concurrent day and day lag 1 and 2) was considered.

Table 4 presents the associations between air pollutants and quintiles of RHR according to current smoking status. Concerning $\mathrm{NO}_{2}$ and $\mathrm{SO}_{2}$ pollution exposures, a positive association with RHR was seen and among current smokers ORs were higher than those recorded for non-smokers. For $\mathrm{O}_{3}$ exposure, a significantly decreasing association with RHR was seen in non-current smokers. 

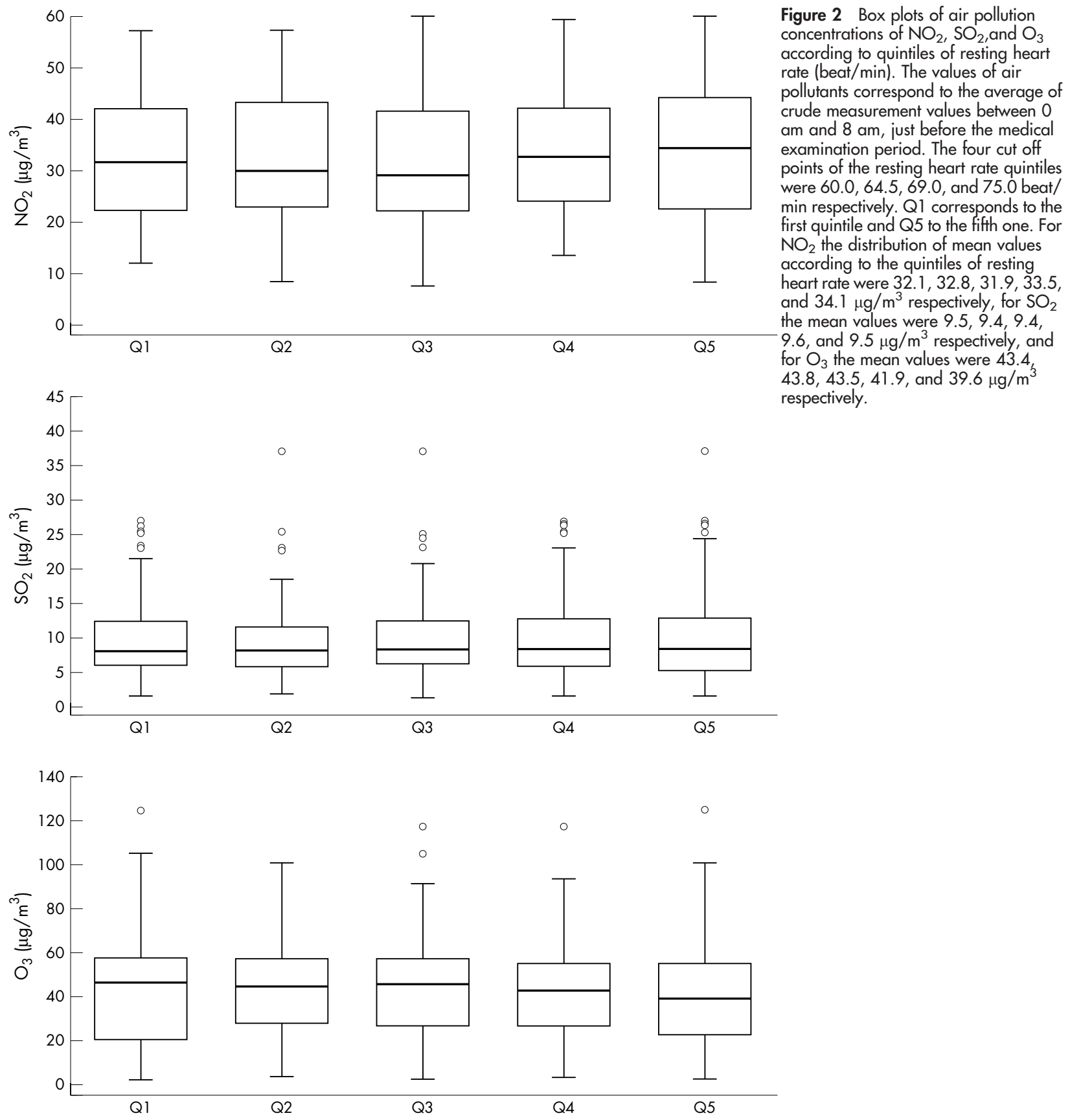

\section{DISCUSSION}

In this cross sectional population based study, air pollution $\left(\mathrm{NO}_{2}\right.$ and $\left.\mathrm{SO}_{2}\right)$ is associated with an increasing RHR. Moreover, $\mathrm{O}_{3}$ exposure is associated with a decreasing RHR although the statistical significance is less obvious.

The pollution exposure heart rate relation was first shown in a population of Augsburg, ${ }^{14}$ during the 1985 European air pollution episode, and even after exclusion of this episode, the relation remained significant. But for the first time this relation was also seen in a population exposed to usually low concentrations of air pollutants, as the mean concentration of $\mathrm{SO}_{2}$ in the metropolitan area of Toulouse (range 2.2-45.7 $\mu \mathrm{g}$ / $\mathrm{m}^{3}$, mean $15.4 \mu \mathrm{g} / \mathrm{m}^{3}$ ) was around three times lower than in the Augsburg area $\left(48.1 \mu \mathrm{g} / \mathrm{m}^{3}\right.$ range $\left.13-103\right)$, the air pollution episode not being considered. These findings support the hypothesis that the relation between RHR and air pollutants occurs at low concentration levels. The notion that there is no threshold for pollutant concentration has already been reported in studies assessing the relation between air pollution and daily mortality. ${ }^{1}$ This association between pollutants and RHR is consistent with a graded relation. The trend was statistically significant for $\mathrm{SO}_{2}$ and $\mathrm{NO}_{2}$ air pollutant concentrations.

The negative association between ozone and RHR has already been reported. Rats exposed to typical experimental concentrations of ozone showed consistent decreases in heart rate. ${ }^{23}$ Short term inhalation of ozone can change activity of sympathetic nerves and catecholamine neurones residing in several central areas. ${ }^{24}$ Cross sectional findings suggest that higher ambient pollutant concentrations are associated with lower cardiac autonomic control..$^{25}$ 
Table 3 Odds ratios (ORs) of daily levels of air pollutants according to quintiles of resting heart rate

\begin{tabular}{|c|c|c|c|c|c|c|}
\hline & \multicolumn{5}{|c|}{ Heart rate (bpm) } & \multirow[b]{4}{*}{$p$ for trend } \\
\hline & \multirow{2}{*}{$\frac{Q 1}{<60.0}$} & \multirow{2}{*}{$\frac{\text { Q2 }}{60.0-64.4}$} & \multirow{2}{*}{$\frac{Q 3}{64.5-67.4}$} & \multirow{2}{*}{$\frac{\text { Q4 }}{67.5-74.9}$} & \multirow{2}{*}{$\frac{\text { Q5 }}{\geqslant 75.0}$} & \\
\hline & & & & & & \\
\hline & $n=159$ & $n=158$ & $n=168$ & $n=179$ & $n=199$ & \\
\hline \multicolumn{7}{|l|}{$\mathrm{NO}_{2}\left(\mu \mathrm{g} / \mathrm{m}^{3}\right) \mathrm{OR}$ and $95 \% \mathrm{Cl}$} \\
\hline \multirow[t]{2}{*}{ same day 0 am-12 pm } & 1 & 0.98 & 1.07 & 1.07 & 1.11 & 0.005 \\
\hline & & 0.89 to 1.10 & 0.97 to 1.18 & 0.97 to 1.18 & 1.01 to 1.23 & \\
\hline \multirow[t]{2}{*}{ same day 0 am-8 am } & 1 & 1.04 & 1.02 & 1.08 & 1.14 & 0.003 \\
\hline & & 0.94 to 1.14 & 0.92 to 1.12 & 0.98 to 1.19 & 1.03 to 1.25 & \\
\hline \multirow{2}{*}{ same day 0 am-12 am } & 1 & 1.02 & 0.99 & 1.01 & 1.12 & 0.02 \\
\hline & & 0.92 to 1.12 & 0.90 to 1.10 & 0.91 to 1.11 & 1.02 to 1.23 & \\
\hline \multirow{2}{*}{ same day $12 \mathrm{am}-12 \mathrm{pm}$} & 1 & 0.96 & 1.06 & 1.04 & 1.06 & 0.03 \\
\hline & & 0.88 to 1.5 & 0.98 to 1.15 & 0.95 to 1.13 & 0.98 to 1.15 & \\
\hline \multirow[t]{2}{*}{ previous day D-1 } & 1 & 1.02 & 0.96 & 1.04 & 1.05 & 0.16 \\
\hline & & 0.92 to 1.12 & 0.87 to 1.06 & 0.95 to 1.14 & 0.96 to 1.16 & \\
\hline \multirow[t]{2}{*}{ previous day D-2 } & 1 & 1.01 & 1.01 & 1.02 & 1.07 & 0.13 \\
\hline & & 0.91 to 1.12 & 0.91 to 1.12 & 0.92 to 1.13 & 0.97 to 1.18 & \\
\hline \multirow[t]{2}{*}{ three day mean D0,D-1,D-2 } & 1 & 1.01 & 1.02 & 1.07 & 1.12 & 0.02 \\
\hline & & 0.89 to 1.15 & 0.90 to 1.15 & 0.95 to 1.21 & 0.99 to 1.27 & \\
\hline \multirow{2}{*}{ three day mean $D-1, D-2, D-3$} & 1 & 1.01 & 1.01 & 1.07 & 1.11 & 0.04 \\
\hline & & 0.89 to 1.14 & 0.89 to 1.14 & 0.94 to 1.21 & 0.98 to 1.26 & \\
\hline \multirow{2}{*}{$\begin{array}{l}\mathrm{SO}_{2}\left(\mu \mathrm{g} / \mathrm{m}^{3}\right) \mathrm{OR} \text { and } 95 \% \mathrm{Cl} \\
\text { same day } 0 \mathrm{am}-12 \mathrm{pm}\end{array}$} & & & & & & \\
\hline & 1 & $\begin{array}{l}0.96 \\
0.81 \text { to } 1.14\end{array}$ & $\begin{array}{l}1.10 \\
0.9 \text { to } 1.29\end{array}$ & $\begin{array}{l}1.12 \\
0.95 \text { to } 1.31\end{array}$ & $\begin{array}{l}1.19 \\
1.02 \text { to } 1.39\end{array}$ & 0.003 \\
\hline \multirow{2}{*}{ same day 0 am-8 am } & 1 & 1.01 & 1.04 & 1.13 & 1.16 & 0.05 \\
\hline & & 0.81 to 1.26 & 0.83 to 1.29 & 0.91 to 1.39 & 0.94 to 1.44 & \\
\hline same day 0 am-12 am & 1 & 0.98 & 1.02 & 1.09 & 1.15 & 0.02 \\
\hline & & 0.82 to 1.17 & 0.86 to 1.22 & 0.92 to 1.29 & 0.97 to 1.36 & \\
\hline same day 12 am-12 pm & 1 & 0.96 & 1.10 & 1.10 & 1.14 & 0.004 \\
\hline & . & 0.83 to 1.11 & 0.97 to 1.26 & 0.96 to 1.25 & 1.01 to 1.30 & \\
\hline previous day D-1 & 1 & 0.90 & 0.90 & 0.97 & 1.01 & 0.46 \\
\hline & & 0.77 to 1.05 & 0.77 to 1.05 & 0.84 to 1.12 & 0.87 to 1.17 & \\
\hline previous day D-2 & 1 & 0.92 & 0.93 & 0.91 & 0.98 & 0.92 \\
\hline & & 0.80 to 1.08 & 0.80 to 1.09 & 0.78 to 1.07 & 0.84 to 1.14 & \\
\hline three day mean D0,D-1,D-2 & 1 & 0.89 & 0.95 & 0.99 & 1.06 & 0.18 \\
\hline & & 0.73 to 1.09 & 0.78 to 1.15 & 0.82 to 1.19 & 0.88 to 1.27 & \\
\hline three day mean D-1,D-2,D-3 & 1 & 0.91 & 0.93 & 0.96 & 1.03 & 0.65 \\
\hline & & 0.74 to 1.10 & 0.76 to 1.13 & 0.79 to 1.15 & 0.85 to 1.24 & \\
\hline $\mathrm{O}_{3}\left(\mu \mathrm{g} / \mathrm{m}^{3}\right)$ OR and $95 \% \mathrm{Cl}$ & & & & & & \\
\hline same day 0 am-12 pm & 1 & 1.02 & 0.99 & 1.03 & 0.95 & 0.20 \\
\hline & & 0.95 to 1.09 & 0.92 to 1.06 & 0.97 to 1.11 & 0.89 to 1.02 & \\
\hline same day 0 am-8 am & 1 & 1.00 & 1.00 & 0.99 & 0.96 & 0.11 \\
\hline & & 0.95 to 1.05 & 0.95 to 1.05 & 0.94 to 1.04 & 0.91 to 1.01 & \\
\hline same day 0 am-12 am & 1 & 1.00 & 0.99 & 0.99 & 0.96 & 0.08 \\
\hline & & 0.95 to 1.06 & 0.94 to 1.05 & 0.93 to 1.04 & 0.90 to 1.01 & \\
\hline same day 12 am-12 pm & 1 & 1.03 & 0.97 & 1.00 & & 0.11 \\
\hline & & 0.96 to 1.11 & 0.91 to 1.04 & 0.93 to 1.07 & 0.89 to 1.02 & \\
\hline previous day D-1 & 1 & 1.02 & 1.00 & 0.96 & 0.96 & 0.07 \\
\hline & & 0.96 to 1.10 & 0.94 to 1.08 & 0.90 to 1.03 & 0.90 to 1.03 & \\
\hline previous day D-2 & 1 & 0.98 & 1.00 & & 0.98 & 0.37 \\
\hline & & 0.91 to 1.04 & 0.93 to 1.07 & 0.91 to 1.04 & 0.91 to 1.04 & \\
\hline three day mean $D 0, D-1, D-2$ & 1 & 1.01 & 1.00 & 0.96 & 0.93 & 0.02 \\
\hline & & 0.93 to 1.09 & 0.93 to 1.08 & 0.89 to 1.04 & 0.86 to 1.01 & \\
\hline three day mean $D-1, D-2, D-3$ & 1 & 0.95 & 0.98 & & & 0.15 \\
\hline & & 0.88 to 1.03 & 0.91 to 1.06 & 0.88 to 1.03 & 0.87 to 1.01 & \\
\hline $\begin{array}{l}\text { For } \mathrm{NO}_{2} \text { and } \mathrm{SO}_{2} \text { multivariate } \\
\text { for hypertension or heart diseas } \\
\text { the average of pollutant measu } \\
\text { period immediately preceding } \\
\text { am, before and during the med } \\
12 \text { pm, just after the medical ex } \\
\text { medical examination. "Previou } \\
\text { "Three day mean DO,D-1,D-2" } \\
\text { before. "Three day mean D-1, } \\
\text { given for an increase of } 5 \text { ( } \mu \mathrm{g} /\end{array}$ & ime. "Sam & $\begin{array}{l}\text { average of pollu } \\
\text { ncentration of a } \\
\text { erage concentro }\end{array}$ & $\begin{array}{l}\text { tlutants over th } \\
\text { ol mair pollutant }\end{array}$ & $\begin{array}{l}\text { ge of pollutant } \\
\text { iverage of pollut } \\
\text { erage of polluta } \\
\text { lutant measuren } \\
\text { r } 24 \text { hours, two } \\
\text { lays; on the sam } \\
\text { r three days be }\end{array}$ & $\begin{array}{l}\text { ssure, cardiovasc } \\
\text { ne day } 0-12 \mathrm{pm} \\
\text { isurements betwe } \\
\text { measurements b } \\
\text { neasurements of } \\
\text { ts over } 24 \text { hours, } \\
\text { ys before the me } \\
\text { day of the exami } \\
\text { examination. }\end{array}$ & $\begin{array}{l}\text { ar drug use (dru } \\
f^{\prime \prime}: \text { corresponds } \\
0 \text { am and } 8 \text { an } \\
\text { veen } 0 \text { am and } \\
\text { tween } 12 \text { am a } \\
\text { ne day before } \\
\text { cal examination } \\
\text { tion and two da } \\
\text { with } 95 \% \mathrm{Cl} \text { we }\end{array}$ \\
\hline
\end{tabular}

The cross sectional design of the study could be a limitation, as a causal relation between RHR and air pollutant concentrations cannot be validated. Pollution risk factors were measured as ecological variables, using the measurements provided by the urban monitoring stations, assuming that exposure was homogenous all over the studied area, thus limiting the strength of the relation, because of a probable exposure misclassification for some people. Indeed exposure misclassification would only bias to the null and the association could be underestimated. ${ }^{26}$
Several confounders could influence the relation between RHR and air pollutants. A potential time clustering could influence the association between RHR and air pollutants, the subjects were recruited at random from the polling lists and the appointment of the examination was made at random too. However, temporal confounding by a variable running in parallel with air pollutant levels over time cannot be ruled out and could explain the findings in part or fully. The values of air pollution concentrations are associated with each day of the week, particularly for $\mathrm{NO}_{2}$ and $\mathrm{SO}_{2}$. An 
Table 4 Odds ratios (ORs) of air pollutants according to quintiles of resting heart rate and current smoking status

\begin{tabular}{|c|c|c|c|c|c|c|}
\hline & \multicolumn{5}{|c|}{ Heart rate (beat $/ \mathrm{mn}$ ) } & \multirow[b]{4}{*}{$p$ for trend } \\
\hline & \multirow{2}{*}{$\frac{Q 1}{<60.0}$} & \multirow{2}{*}{$\frac{\text { Q2 }}{60.0-64.4}$} & \multirow{2}{*}{$\frac{Q 3}{64.5-67.4}$} & \multirow{2}{*}{$\frac{Q 4}{67.5-74.9}$} & \multirow{2}{*}{$\begin{array}{l}\text { Q5 } \\
\geqslant 75.0\end{array}$} & \\
\hline & & & & & & \\
\hline & $n=122 / 37$ & $n=123 / 36$ & $n=139 / 36$ & $n=139 / 40$ & $n=159 / 39$ & \\
\hline $\begin{array}{l}\mathrm{NO}_{2}\left(\mu \mathrm{g} / \mathrm{m}^{3}\right) \text { same day } 0 \mathrm{am}-8 \mathrm{am} \\
\text { non-current smokers }\end{array}$ & 1 & $\begin{array}{l}1.03 \\
0.92 \text { to } 1.15\end{array}$ & $\begin{array}{l}0.98 \\
0.88 \text { to } 1.10\end{array}$ & $\begin{array}{l}1.04 \\
0.93 \text { to } 1.16\end{array}$ & $\begin{array}{l}1.09 \\
0.98 \text { to } 1.22\end{array}$ & 0.04 \\
\hline current smokers & 1 & $\begin{array}{l}1.07 \\
0.86 \text { to } 1.32\end{array}$ & $\begin{array}{l}1.10 \\
0.89 \text { to } 1.36\end{array}$ & $\begin{array}{l}1.21 \\
0.98 \text { to } 1.49\end{array}$ & $\begin{array}{l}1.28 \\
1.04 \text { to } 1.58\end{array}$ & 0.02 \\
\hline $\begin{array}{l}\mathrm{SO}_{2}\left(\mu \mathrm{g} / \mathrm{m}^{3}\right) \text { same day } 0 \mathrm{am}-8 \mathrm{am} \\
\text { non-current smokers }\end{array}$ & 1 & $\begin{array}{l}1.01 \\
0.79 \text { to } 1.29\end{array}$ & $\begin{array}{l}0.96 \\
0.74 \text { to } 1.23\end{array}$ & $\begin{array}{l}1.06 \\
0.83 \text { to } 1.35\end{array}$ & $\begin{array}{l}1.08 \\
0.44 \text { to } 1.38\end{array}$ & 0.28 \\
\hline current smokers & 1 & $\begin{array}{l}1.09 \\
0.62 \text { to } 1.89\end{array}$ & $\begin{array}{l}1.45 \\
0.86 \text { to } 2.44\end{array}$ & $\begin{array}{l}1.44 \\
0.86 \text { to } 2.41\end{array}$ & $\begin{array}{l}1.63 \\
0.98 \text { to } 2.71\end{array}$ & 0.03 \\
\hline $\begin{array}{l}\mathrm{O}_{3}\left(\mu \mathrm{g} / \mathrm{m}^{3}\right) \text { three day } \mathrm{D} 0, \mathrm{D}-1, \mathrm{D}-2 \\
\text { non-current smokers }\end{array}$ & 1 & $\begin{array}{l}1.03 \\
0.94 \text { to } 1.13\end{array}$ & $\begin{array}{l}1.01 \\
0.92 \text { to } 1.10\end{array}$ & $\begin{array}{l}0.99 \\
0.91 \text { to } 1.08\end{array}$ & $\begin{array}{l}0.93 \\
0.85 \text { to } 1.01\end{array}$ & 0.04 \\
\hline current smokers & 1 & $\begin{array}{l}0.92 \\
0.77 \text { to } 1.10\end{array}$ & $\begin{array}{l}0.99 \\
0.83 \text { to } 1.18\end{array}$ & $\begin{array}{l}0.87 \\
0.73 \text { to } 1.04\end{array}$ & $\begin{array}{l}0.95 \\
0.80 \text { to } 1.14\end{array}$ & 0.39 \\
\hline $\begin{array}{l}\text { For } \mathrm{NO}_{2} \text { and } \mathrm{SO}_{2} \text { multivariate models } \\
\text { for hypertension or heart diseases), an } \\
\text { average of the measurements of pollut } \\
\text { average concentration of air pollutants } \\
\text { smokers. ORs with } 95 \% \mathrm{Cl} \text { were given }\end{array}$ & $\begin{array}{l}\text { adjusted for } \\
\text { reactive prote } \\
\text { between } 0 \text { an } \\
\text { three days; o } \\
\text { an increase o }\end{array}$ & $\begin{array}{l}\text { nths, relative } \\
\mathrm{O}_{3} \text { an additio } \\
\text { am, just befor } \\
\text { ime day of the } \\
\mathrm{m}^{3} \text { ) of } \mathrm{NO}_{2} \text {, }\end{array}$ & $\begin{array}{l}\text { ility, physical a } \\
\text { adjustment for } t \\
\text { e medical exam } \\
\text { nination and tw } \\
\text { and } \mathrm{O}_{3} \text {. }\end{array}$ & $\begin{array}{l}\text { systolic blood } \\
\text { ature was don } \\
\text { n time. Three d } \\
\text { s before. } \mathrm{N}=\mathrm{n}\end{array}$ & $\begin{array}{l}\text { sure, cardiovas } \\
\text { ame day } 0-8 \text { o } \\
\text { nean DO,D-1,D } \\
\text { 2: number of no }\end{array}$ & $\begin{array}{l}\text { ar drug use }(\mathrm{dr} \\
\text { orresponds to } \\
\text { corresponds to } \\
\text { nokers/numbe }\end{array}$ \\
\hline
\end{tabular}

additional adjustment for the days of the week was made in logistic models. No changes were seen in statistical results.

Other potential confounders were tested, particularly the place of residence, socio-professional and occupational status. The polytomous logistic regression models were adjusted also for these parameters and the results were not modified significantly because probably less specific, less accurate proxy variables were used in this study to estimate occupational exposure, and also because a short time effect of exposure on RHR (a few hours) was observed. Moreover, the interaction of occupational exposure on pathology-pollution relation is more frequently seen, with an additive or synergistic effect, in a long term exposure. This adjustment did not enable us to discard completely either the potential

\section{Policy implications}

- Improve health workers' knowledge and information of the global population about health risk attributable to pollution and its impact on the most vulnerable persons. Promote rapid and basic reactions when peak of pollution are forecasted.

- Maintain and reinforce air quality network monitoring and alarm systems in rural and urban areas in each country (http://www.euro.who.int/air).

- Necessary actions at several levels to reduce air pollution exposure: improve national and international legislation, collaborate with sectors responsible for air pollution and with national and regional authorities in charge of traffic and industry.

- Reduce pollutant emission from traffic and factories by different means: reduction of traffic by developing public transports, reduction of vehicle speed, development of new technologies to improve efficiency of car engines, promotion of the research of new sources of less polluting energies.

- Ensure a healthy environment for the next generation through these various public policies. influence of occupational exposure, not actually taken into account in this study, or a potential influence of indoor pollutants.

A tobacco-pollution interaction term was introduced in the statistical models and the influence of smoking on pollutionheart rate relation was tested. The statistical significance of the interaction term was never reached whatever the model or the exposure considered. Lastly, this relation was studied among smokers and non-smokers because smokers may develop long term increases in cardiac rate, changes in cardiovascular control, ${ }^{27}$ and acute exposure to tobacco smoke increases cardiac vulnerability and heart rate. ${ }^{28}$ When the relations were tested separately in smokers and non-smokers, the trends of ORs were similar but the strength of the associations for nitrogen and sulphur dioxides were superior among smokers linked to a probable additive effect between smoking and pollution exposure.

It is difficult to estimate health risk on the autonomic nervous system, specifically associated with outdoor $\mathrm{NO}_{2}$ or $\mathrm{SO}_{2}$ as they are present in urban ambient air mixtures with other major pollutants. Hence, nitrogen dioxide and sulphur dioxide might be considered as indicators of polluted ambient air, especially when they represent the major components of air pollution in our study area ${ }^{4}$ characterised by a traffic dominated air pollution mixture. In other respects, experimental studies on the interaction of $\mathrm{NO}_{2}$ with $\mathrm{SO}_{2}$ or with other common pollutants has not been extensively studied

\section{Key points}

- The positive association between air pollutants and resting heart rate is a graded and continuous relation.

- Change in the autonomic nervous system is a potential mechanism involved in the deleterious impact of air pollution on cardiovascular morbidity.

- Even a population of apparently healthy young adults is not protected against air pollution.

- The impact of air pollution on the resting heart rate can be seen even at low concentration levels of pollutants. 


\section{Knowledge on the topic}

- Studies have put forward the hypothesis that particulate matter may influence cardiovascular risk partly by the disturbance of cardiac autonomic function such as modifications in the heart rate variability. Impacts of other pollutants such as $\mathrm{NO}_{2}, \mathrm{SO}_{2}$, and $\mathrm{O}_{3}$ have been less investigated.

- The associations between pollution and the autonomic nervous system have been predominantly investigated in vulnerable populations: elderly subjects or patients with history of heart disease.

and the number of end points is limited, in particular the influence of the mixture of $\mathrm{SO}_{2}$ and $\mathrm{NO}_{2}$ on RHR or heart rate variability has not been explored sufficiently.

The relation with air pollutant concentrations was significant particularly when the analyses were performed with RHR and $\mathrm{SO}_{2}$ or $\mathrm{NO}_{2}$, measured on the same day. Moreover, for $\mathrm{NO}_{2}$, the strength of the relation was higher when the immediately preceding period ( 0 am to $8 \mathrm{am}$ ) was considered as compared with the period after the medical examination ( $12 \mathrm{am}$ to $12 \mathrm{pm}$ ). For $\mathrm{SO}_{2}$, the ORs in the fifth quintiles of RHR were similar between the before and after periods of examination. However, the $\mathrm{p}$ value for trend was higher for the period after the medical examination. The subtle differential relation design between the two gaseous pollutants could be explained by a low reactivity and a low solubility of $\mathrm{NO}_{2}$ enabling its penetration into the periphery of the lung. ${ }^{29}$ After absorption $\mathrm{NO}_{2}$ is transformed in nitric acid and then in nitrite ion in blood circulation, inducing methemoglobin formation after a lag period. ${ }^{30} 31$

When time lag 1, 2, or 3 was considered, no association (ORs close to 1) with RHR was noticed. Moreover, no cumulative effect of pollutant concentrations was established when the mean of the two or the three days before the RHR measurement was considered, the ORs were similar to those seen for the concurrent day of exposure. Even if the response to volunteers' exposure (to $\mathrm{SO}_{2}$ for instance in a controlled experiment chamber), occurs within a few minutes, the lack of association between RHR and the values of pollutants in day lag 1, 2, or 3 could be explained by the low concentrations of these parameters in the air of the studied area and the limited number of days with high concentration values of pollutants. For ozone, the only significant trend ascertained when the cumulative effect was tested could be explained by the reduction of the within variability of exposure in relation to the between variability and the lack of significance observed for day lag 1 exposure could originate from an insufficient statistical power. Finally, the age of the population studied ranging from 35 to 64 years limits the generalisation of the conclusions because subjects aged over 64 years are more vulnerable to pollution exposure than younger ones.

In conclusion, the pathophysiological relevance of the association between RHR and pollutants remains to be established. The stimulation of a systemic sympathetic stress response by air pollution may lead not only to increased heart rate but also to lower heart rate variability and increased ventricular arrhythmias. ${ }^{32} 33$ Despite some limitations of the study, we showed that RHR increases with air pollution concentration $\left(\mathrm{NO}_{2}, \mathrm{SO}_{2}\right)$ among an apparently healthy population of a metropolitan area.

\section{ACKNOWLEDGEMENTS}

We thank the "Fédération Française de Cardiologie (FFC)", the "Institut National de la Santé et de la Recherche Médicale
What the paper adds

- Our study shows that exposure to pollution may affect a population of young adults without apparently associated serious diseases.

- The impact of air pollution on the autonomic nervous system can be observed even at low concentration levels of air pollutants.

- Gaseous pollutants as well as particulate matter may influence resting heart rate.

(INSERM)", the "Direction Générale de la Santé (DGS)", the "Observatoire Régional de l'Air en Midi-Pyrénées (ORAMIP)", the "Agency for Environment and Energy Management (ADEME)", the "Fondation de France", for their financial or methodological supports enabling this work. We also thank Thibaud Bouillie for having prepared the database with great care. We appreciate the collaboration with the INSEE.

\section{Authors' affiliations}

J-B Ruidavets, M Cournot, V Bataille, J Ferrières, INSERM U558, Department of Epidemiology, University School of Medicine, Toulouse, France

S Cassadou, InVS, Toulouse, France

M Meybeck, ORAMIP, Toulouse, France

Competing interests: none.

\section{REFERENCES}

1 Vedal S, Brauer $M$, White $R$, et al. Air pollution and daily mortality in a city with low levels of pollution. Environ Health Perspect 2003;1 11:45-52.

2 Le Tertre A, Medina S, Samoli E, et al. Short-term effects of particulate air pollution on cardiovascular diseases in eight European cities. J Epidemiol Community Health 2002;56:773-9.

3 Ballester F, Tenias JM, Perez-Hoyos S. Air pollution and emergency hospital admissions for cardiovascular diseases in Valencia, Spain. J Epidemiol Community Health 2001;55:57-65.

4 APHEIS. Health impact assessment of air pollution in 26 European cities: APHEIS second-year report 2000-2001. Saint-Maurice: APHEIS, 2002.

5 Ruidavets JB, Cournot M, Cassadou S, et al. Ozone air pollution is associated with acute myocardial infarction. Circulation 2005;111:563-9.

6 Brook RD, Franklin B, Cascio W, et al. Expert Panel on Population and Prevention Science of the American Heart Association. Air pollution and cardiovascular disease: a statement for healthcare professionals from the Expert Panel on Population and Prevention Science of the American Heart Association, Circulation 2004;109:2655-71.

7 Routledge HC, Ayres JG, Townend JN. Why cardiologists should be interested in air pollution. Heart 2003;89:1383-8.

8 Holguin F, Tellez-Rojo MM, Hernandez $M$, et al. Air pollution and heart rate variability among the elderly in Mexico City. Epidemiology 2003;14:521-7.

9 Peters A, Liu E, Verrier RL, et al. Air pollution and incidence of cardiac arrhythmia. Epidemiology 2000;11:11-17.

10 Greenland P, Daviglus ML, Dyer AR, et al. Resting heart rate is a risk factor for cardiovascular and noncardiovascular mortality: the Chicago heart association detection project in industry. Am J Epidemiol 1999;149:853-62

11 Mensink GB, Hoffmeister $H$. The relationship between resting heart rate and all-cause, cardiovascular and cancer mortality. Eur Heart $J$ 1997; 18:1404-10.

12 Kannel WB, Kannel C, Paffenbarger RS Jr, et al. Heart rate and cardiovascular mortality: the Framingham study. Am Heart J 1987; 113:1489-94.

13 Kristal-Boneh E, Silber $\mathrm{H}$, Harari $\mathrm{G}$, et al. The association of resting heart rate with cardiovascular, cancer and all-cause mortality. Eight year follow-up of 3527 male Israeli employees (the CORDIS study). Eur Heart J 2000;21:116-24.

14 Peters A, Perz S, Doring A, et al. Increases in heart rate during an air pollution episode. Am J Epidemiol 1999;150:1094-8.

15 Pope CA, Dockery DW, Kanner RE, et al. Oxygen saturation, pulse rate, and particulate air pollution: A daily time-series panel study. Am J Respir Crit Care Med 1999; 159:365-72.

16 Ferrières J, Ruidavets JB. Association between resting heart rate and hypertension treatment in a general population. Am J Hypertens 1999; 12:628-31

17 Ruidavets JB, Ducimetière $P$, Arveiler $D$, et al. Types of alcoholic beverages and blood lipids in a French population. J Epidemiol Community Health 2002; $56: 24-8$.

18 ADEME. Classification and criteria for setting up air quality monitoring stations. Paris: ADEME Editions, 2002. 
19 ADEME. Classification et critères d'implantation des stations de surveillance de la qualité de l'air. Recommandation du groupe de travail caractérisation des sites. Paris: ADEME Editions, 1999.

20 Pope CA, Kalstein LS. Synoptic weather modeling and estimates of the exposure-response relationship between mortality and particulate air pollution. Environ Health Perspect 1996;104:414-20.

21 Katsouyanni K, Schwartz J, Spix C, et al. Short term effects of air pollution on health: a European approach using epidemiologic time series data: the APHEA protocol. J Epidemiol Community Health 1996;50(suppl 1):S12-18.

22 Morcet JF, Safar M, Thomas F, et al. Associations between heart rate and other risk factors in a large French population. J Hypertens 1999;17:1671-6.

23 Watkinson WP, Campen MJ, Nolan JP, et al. Cardiovascular and systemic responses to inhaled pollutants in rodents: effects of ozone and particulate matter. Environ Health Perspect 2001;109(suppl 4):539-46.

24 Soulage C, Perrin D, Cottet-Emard JM, et al. Central and peripheral changes in catecholamine biosynthesis and turnover in rats after a short period of ozone exposure. Neurochem Int 2004;45:979-86

25 Liao D, Duan Y, Whitsel EA, et al. Association of higher levels of ambient criteria pollutants with impaired cardiac autonomic control: a populationbased study. Am J Epidemiol 2004;159:768-77.
26 Armstrong BG. Effect of measurement error on epidemiological studies of environmental and occupational exposures. Occup Environ Med 1998;55:651-6.

27 Hirsch JA, Bishop B, York JL. Role of parasympathetic (vagal) cardiac control in elevated heart rates of smokers. Addict Biol 1996;1:405-13.

28 Pope CA, Eatough DJ, Gold DR, et al. Acute exposure to environmental tobacco smoke and heart rate variability. Environ Health Perspect 2001;109:711-16

29 Grella E, Paciocco G, Caterino U, et al. Respiratory function and atmospheric pollution. Monaldi Arch Chest Dis 2002:57:196-9.

30 Steinhaus RK, Baskin SI, Clark JH, et al. Formation of methemoglobin and metmyoglobin using 8-aminoquinoline derivatives or sodium nitrite and subsequent reaction with cyanide. J Appl Toxicol 1990;10:345-51.

31 Troncy E, Francoeur M, Blaise G. Inhaled nitric oxide: clinical applications, indications, and toxicology. Can J Anaesth 1997;44:973-88.

32 Stone PH, Godleski JJ. First steps toward understanding the pathophysiologic link between air pollution and cardiac mortality. Am Heart 1999; 138:804-7

33 Habib G. Reappraisal of the importance of heart rate as a risk factor for cardiovascular morbidity and mortality. Clin Ther 1997;19(suppl A):39-52.

\section{bmjupdates+}

bmjupdates+ is a unique and free alerting service, designed to keep you up to date with the medical literature that is truly important to your practice.

bmjupdates+ will alert you to important new research and will provide you with the best new evidence concerning important advances in health care, tailored to your medical interests and time demands.

Where does the information come from?

bmjupdates+ applies an expert critical appraisal filter to over 100 top medical journals A panel of over 2000 physicians find the few 'must read' studies for each area of clinical interest

Sign up to receive your tailored email alerts, searching access and more...

www.bmjupdates.com 